\title{
Presencia y archivo: estrategias documentales en dos montajes teatrales chilenos ${ }^{1}$
}

\author{
Presence and Archive: Documentary Strategies in two Chilean \\ Plays \\ Catalina Donoso Pinto \\ Universidad de Chile \\ catalina.donoso@uchile.cl
}

\section{Resumen}

El presente trabajo examina dos montajes chilenos estrenados en 2017: Nuke dirigido por Paula González Seguel y Mateluna dirigido por Guillermo Calderón: la primera aborda la violencia en las comunidades mapuche y la segunda se enfoca en colectivos organizados de resistencia radical a la dictadura cívico-militar. El análisis de las obras se centra en reconocer ciertas estrategias que cada una utiliza y que interrogan las relaciones entre el espacio de la puesta en escena y el terreno extradiegético. En el caso de Ñuke a través de la inclusión de elementos de carácter documental; en Mateluna, por su reapropiación del material de archivo.

Palabras clave: teatro chileno, documentalidad, archivo, conflictos sociales, Guillermo Calderón, Paula González Seguel.

\begin{abstract}
This article examines two Chilean plays that premiered in 2017: Nuke directed by Paula González Seguel, and Mateluna directed by Guillermo Calderón. The first addresses the violence that affects Mapuche communities in the present, while the second focuses on the radical resistance organizations that fought against the Chilean dictatorship. The analysis of these two works centers on some strategies they use to question the relations and boundaries between the staging and the extradiegetic dimension. In $\tilde{N} u k e$, this is done by including documentary elements; in Mateluna, through its reappropriation of the archive.
\end{abstract}

Keywords: Chilean Theater, documentary, archive, social conflict, Guillermo Calderón, Paula González Seguel.

1 Este artículo se enmarca dentro del desarrollo del proyecto Fondecyt Regular Nro. 1191698 "Documento inestable: una propuesta de archivo performativo y subjetividad material". 
La disposición de parte de algunas compañías nacionales por integrar en sus montajes elementos de carácter documental ha crecido en los últimos años. El investigador chileno Mauricio Barría utilizó el término "emergencias documentales", para describir esta tendencia y caracterizarla en concordancia con una recuperación del interés por la historicidad en la constitución de un teatro político en la actualidad. Al contextualizar dicha tendencia, Barría señala las movilizaciones sociales que se radicalizan a partir de 2006 y que marcan el término de la llamada transición, como hitos fundamentales para entender un fenómeno de producción teatral "que se materializó a través de una serie de montajes en los que destacaba la utilización del documental como procedimiento articulador del relato escénico". Por otra parte, en un artículo sobre lo que individualiza como "teatro documento" en tres países del Cono Sur (Argentina, Uruguay y Chile), Cristina Bravo Rozas propone un recorrido temporal de la inclusión del documento como elemento significante dentro de la puesta en escena, que se iniciaría ya desde la fundación de los teatros nacionales. La denominación teatro documental es problemática, así como es insostenible no mencionar sus vinculaciones con el biodrama. Para efectos de este trabajo no es mi intención categorizar los dos componentes del corpus como exponentes del teatro documental, pero sí señalar que algunas de sus estrategias de representación escénica deben estudiarse desde la concepción de un grado mayor de documentalidad, en dos casos que justamente se separan de las operaciones que podrían emparentarlos con el biodrama.

En este sentido, lo que me interesa no es trabajar con el documental como género, sino la documentalidad como práctica de representación. Para definirla recurro a consideraciones provenientes de la teatrología pero incluyo también algunas nociones que pueden recogerse desde los estudios de cine. Esta aproximación está estrechamente vinculada a mi interés por estudiar los cruces e intercambios entre las disciplinas teatral y cinematográfica, y la posibilidad de leerlas en constante retraoalimentación. Es importante además tener en cuenta que se trata de apuestas teatrales que de algún modo han dialogado con la proyección audiovisual en escena (en el caso de González en obras anteriores, y en el de Calderón en la misma Mateluna).

Antes de proponer una idea de documentalidad con la que me interesa trabajar y que tenga como campo de estudio tanto la producción teatral como la cinematográfica, me parece importante exponer distintas aproximaciones que buscan establecer un territorio de intercambios entre ambas disciplinas. 


\section{Espacio fílmico y espacio escénico: para una definición de documentalidad}

No son pocos los autores que han abordado los cruces entre lenguaje teatral y cinematográfico en un itinerario que se inicia a principios del siglo XX con la adopción, por parte del naciente recurso fílmico, de las estrategias narrativas del teatro (con una puesta en escena que en muchos casos no era sino una especie de "teatro filmado"), para luego dar paso a la influencia que las estrategias del relato fílmico (ya constituido en lenguaje) tuvo en la escena teatral. En este sentido, se pueden mencionar al menos dos aproximaciones, la de Vsevolod Meyerhold y su noción de "cineficación de la escena", y la de André Bazin que propone dos modos de entender la creación del espacio de la representación según se planteen desde la ficción teatral o la diégesis fílmica. Es relevante señalar que estos autores se sitúan respectivamente desde la teatralidad -Meyerhold-y la teoría del cine-Bazin-; así, aparecen como miradas complementarias para explorar el fenómeno. Es también importante señalar, en el caso de Meyerhold, que además de sus contribuciones al campo de las artes escénicas, tanto desde la práctica como la teoría, tuvo un vínculo estrecho con uno de los pilares de la cinematografía, Sergei Eisenstein. Este último fue su ayudante y colaborador, hecho que confirma, además, los intercambios tempranos entre ambas disciplinas. La concepción de una "cineficación del teatro" tenía menos que ver con la irrupción de la tecnología cinematográfica dentro de la escena (cosa que de todas formas el autor exploró), que con el traslado de los hallazgos derivados de la evolución fílmica hacia su constitución como lenguaje autónomo, hacia el espacio teatral.

Vuelvo ahora a Bazin. En su ya canónico texto ¿Qué es el cine?, el teórico francés dedica un apartado a reflexionar en torno a los universos discursivos creados por la ficción cinematográfica y la teatral. Esta última la reconoce liderada por una fuerza centrípeta que nos obliga a mirar dentro de lo que ocurre en el escenario, mientras la segunda se somete a una fuerza centrífuga de un encuadre que dialoga con lo que está fuera de él. En su propuesta, el espacio teatral constriñe nuestra mirada, mientras el cinematográfico la amplía. Probablemente uno de los textos más relevantes que interroga teóricamente la relación entre teatro y cine sea "Film and Theatre" (1966) de Susan Sontag. El propósito fundamental del ensayo es tensionar la idea de una especificidad de cada lenguaje. Revisando y actualizando las propuestas de teóricos provenientes del campo del arte y el teatro (algunos de ellos también directores), como Panofsky, Artaud o Meyerhold; Sontag reconoce el tránsito -ya establecido antes- en que la influencia del teatro en el cine da lugar al movimiento opuesto y luego a un estadio, no bien definido aún, de diálogos e intercambios. El aporte crucial del texto es que su conclusión se plantea como un desafío que busca desmantelar la oposición binaria que reconoce, o bien una pureza específica de 
cada arte, o bien una suerte de contaminación productiva entre ellos. Su invitación es a pensar una tercera opción que no cierra los espacios disciplinarios (ya como límite infranqueable o como frontera de tránsito).

Teniendo estos antecedentes en consideración es que me permito proponer un análisis de ambas obras, donde la idea de documentalidad se plantea en diálogo con los aportes que el cine como lenguaje ha desarrollado en torno al género documental y sus alcances. Lo primero que es preciso tener en cuenta es que el cine primitivo surge desde lo que Francois Jost y André Gaudreault denominan el "grado cero de la documentalidad". Las primeras piezas de cine primitivo, registradas y luego exhibidas por los hermanos Lumière, no son sino observaciones frontales de un hecho, sin ninguna o escasa aspiración narrativa. Podríamos decir que, por el contrario, el teatro moderno se funda en la creación de un lugar eminentemente ficcional que se instituye en la escena. En este sentido, la pregunta por la documentalidad ha sufrido más crisis y transformaciones en el debate de los estudios de cine que en el ámbito de la teatrología. Creo necesario señalar que la discusión que ha intentado definir lo documental -más que el documental- como género, se sitúa sobre todo en una posición que no zanja los espacios de ficción y documentalidad como territorios cerrados, sino como lugares de intercambio y colaboración mutua. La producción de una obra señalada como documental se piensa cada vez más como un ejercicio que, por un lado, se despliega en una performatividad que ocurre en la misma obra, y por otro, no considera al elemento extrafílmico que hace las veces de referente como un real que lo antecede, sino que surge en el territorio de la puesta en escena documental. Para la primera anotación me baso fundamentalmente en lo expuesto por Stella Brussi, quien impugna las categorizaciones desarrollada por Bil Nichols para enfatizar el carácter performartivo de toda práctica documental:

El documental siempre estará circunscrito al hecho de que se trata de un modo de representación, por ende, no podrá nunca eludir la distancia entre la imagen y el suceso que registra. Resulta imperativo, sin embargo, reconocer que esta deficiencia no invalida la idea de un cine de no ficción. Simplemente el cine de no ficción es ( $\mathrm{y}$ así ha sido siempre) consciente de las limitaciones de un medio audiovisual. Con este recononocimiento, lo que surge al examinar la producción documental, es una alerta que incorpora una relación dialéctica entre aspiración y potencial, donde el texto mismo revela las tensiones entre la intención del documental y el más auténtico modo de representación realista y la misma imposibilidad de este propósito $(180){ }^{2}$

2 La traducción es mía. 
En ese sentido, la distancia presente entre ese hipotético real y su representación documental, es la performatividad que se revela en toda pieza documental. En una relación oblicua, para la segunda observación recurro a la idea de indeterminación desarrollada por Emilio Bernini, para superar la noción de hibridez que definiría un modo de cruce entre el documental y la ficción, pero considerándolos territorios cerrados y completos (tal vez en el sentido en que Sontag entiende la consideración más extendida de los diálogos cine/teatro y que ella busca confrontar). Bernini entiende por indeterminado el discurso fílmico documental que no aspira a estos estatutos predefinidos sino en mutua construcción:

La indeterminación . . p presenta un problema de acceso al conocimiento del mundo antes que una confianza en formas como las genéricas en las que el mundo se hace, de una u otra manera, cognoscible. Por esto mismo, la indeterminación produce como efecto de lectura cierto desconcierto mientras que, por el contrario, la hibridación se confirma en el reconocimiento que el espectador hace de ella (295).

Para ambos autores, ese real histórico o suceso extrafílmico es siempre inasible, y el intento por capturarlo define la modalidad documental como la puesta en escena de ese proceso (como performatividad para Bruzzi, o indeterminación para Bernini).

En "Política de la verdad" Hito Steyerl propone que:

La documentalidad describe la penetración de formaciones políticas, sociales y epistemológicas superiores en una política específica de la verdad documental. La documentalidad es el punto donde pivotan, donde las formas de producción de verdad documental, se convierten en gobierno o viceversa. El término describe tanto la complicidad con las formas dominantes de política de la verdad como una actitud crítica hacia estas formas (s/n).

Por su parte, Anna María Guasch, destaca la noción de documentalidad desarrollada por Hito Steyerl para enfatizar una de las formas de entender lo documental, que se opone a una relación de autenticidad o veracidad respecto del mundo representado. Recogiendo el concepto de gubernamentalidad explorado por Michel Foucault, la documentalidad operaría más bien desde "una posición constructivista partiendo de la premisa de que las imágenes documentales son producidas y conformadas por relaciones de poder, tanto las políticas y sociales como los complejos de poder y conocimiento de la ley, la ciencia y el periodismo" (356). Volveré a esto más adelante, en el examen de una de las obras, pero me interesa destacar cómo 
estas aproximaciones no enfatizan un vínculo férreo entre verdad y documento, sino que lo entienden como marca visible de las relaciones de poder que lo hacen posible, y donde la documentalidad se aloja también en las operaciones mismas que dan lugar a estos documentos dentro de un discurso.

$\mathrm{El}$ análisis que me propongo hacer ahora se sostiene desde las reflexiones acerca de la documentalidad que pueden leerse en estos dos trabajos, centrándome en distintos modos que cada montaje privilegia para acercarse a este modo discursivo, enfatizando que en ambos casos se trata de una interrogación al real histórico con el que dialoga y no supone una pura representación pasiva.

\section{$\tilde{N} u k e$ o la presencia}

La compañía Teatro KIMVN ha desarrollado, desde sus inicios, una exploración de los límites de la puesta en escena, a través de la inclusión de elementos documentales dentro del espacio teatral. Su Trilogía documental, que incluye las obras $\tilde{N} i$ Pu Tremen (2008), Territorio Descuajado. Testimonio de un país mestizo (2011) y Galvarino (2012), construye un universo ficcional donde conviven actores junto a no-actores de origen mapuche y la inclusión de sus discursos y prácticas. Su último montaje, Nuke. Una mirada intima hacia la resistencia mapuche (2016), profundiza esta relación entre documento y ficción, incorporando también materiales que desdibujan la separación entre el espacio de la representación y el espectador. En este apartado pretendo examinar esta última producción teatral (teniendo como antecedente la trilogía antes mencionada, especialmente el montaje Galvarino), y así interrogar la entrada de lo real al espacio escénico, abordando la documentalidad como una herramienta puesta al servicio tanto del cuestionamiento de los límites de la puesta en escena como de la producción de un discurso político y ético en relación a las temáticas que trata. Un aspecto relevante del análisis es su aproximación a la idea de género documental, vinculando los aportes del teatro documental con la teoría del documental en el cine. La directora de la compañía, Paula González, cursó recientemente estudios de posgrado en cine documental, para revisar también estos intercambios entre disciplinas, y plantear como productivos los diálogos entre distintos campos del saber y del quehacer artístico.

Me gustaría comenzar estableciendo algunas aproximaciones a la noción de documentalidad, que pongan en relación su concepción desde la escena teatral así como desde el campo fílmico. Cuando abordamos el teatro contemporáneo es difícil no hacer referencia a lo que Hans-Thies Lehmamn denominó teatro posdramático, y que ha tenido un amplio desarrollo desde el pasado siglo. En términos generales, lo que el teatro posdramático impugna son las aproximaciones tradicionales que supeditan la representación teatral al texto escrito. Esta ruptura de 
la hegemonía de la palabra no supone una renuncia a la dimensión textual como aspecto relevante de la puesta en escena, sino que reconoce la relación conflictiva (y por ello productiva) entre su asentamiento inicial en la palabra y la consecuente puesta en escena de ese texto; lo que Lehman llama "parataxis" a fin de proponer una desjerarquización de los distintos medios puestos en juego en la escena. La concepción de Lehman interroga, entonces, una noción de texto que se ancla en la palabra en estricto, para proponer un "espacio hablante", creado tanto por el texto dramático, como por sus silencios y su diálogo con el montaje en un escenario particular. Para definir ese nivel de lo dramático que supera su encarnación en un soporte textual en sentido estricto, Walter Benjamin lo denominaría "representación", mientras que Lehman propone desarticular la oposición binaria verbal/no-verbal. Muchas veces cuando se habla de teatro posdramático, se le suele simplificar como una prescindencia del texto dramático, sin embargo, cuando Hans Lehamn acuña el término, más bien lo plantea intentando definir el teatro moderno como una "historia de la perturbación recíproca entre el texto y la escena" (258), una suerte de "desplazamiento de las jearaquías", como lo definiera antes Antonin Artaud. Es decir, no es que el texto dramático deje de ser relevante, sino que se lo sitúa como un elemento más en un juego de niveles y lenguajes que dan origen a un "espacio hablante", según la concepción del mismo Lehman. En este sentido, si bien el teatro posdramático no sería en rigor un antecedente para el teatro documental, su propuesta define una nueva concepción de lo dramático, que abre la escena a nuevas estrategias de representación y nuevas materialidades. A su vez, el teatro documental como práctica escénica puede rastrearse a inicios del siglo veinte, con momentos álgidos más tarde en la década del 60 y a fines del siglo pasado. Seguramente uno de sus representantes más connotados sea el alemán Roland Brus, quien ha experimentado con la inclusión de no-actores en escena y sus historias de vida como interrogación del espacio dramático, pero también del tejido social, otorgando visibilidad y voz a sujetos marginales. Una aproximación que me interesa sentar es la que diferencia dos modos de entender la documentalidad en el teatro: a través de la inclusión de documentos, por una parte, o de la utilización de testimonios, por otro. En ambos sentidos, la tensión que se perfila es una que relaciona los elementos significantes con la oposición realidad/ficción, y que ha sido bastante explorada desde los estudios del cine. De algún modo, tal como señalé en un inicio, el discurso teatral aparece como uno de ficción por excelencia, mientras el fílmico surge a partir del registro documental, para luego incorporar estrategias ficcionales de narración. Los debates en torno a la interrelación de estos dos géneros o territorios discursivos es extensa y no voy a entrar a detallarla, pero sí me gustaría destacar que las tendencias en el audiovisual contemporáneo son más bien las que plantean una interacción porosa y compleja entre ellos, donde la 
hibridez y sobre todo la indeterminación, a la que hice referencia en la sección inicial de este trabajo, renuncian a oponer como antagónicos los estatutos de la realidad (donde lo documental se afianza) y la ficción. Así, podríamos decir que los estudios del cine nos ayudan a mirar desde este prisma más flexible la irrupción de lo documental en el teatro, y me parece que es desde esa noción que Teatro KIMVN aborda la documentalidad en sus obras.

En Chile, el teatro documental como tendencia consolidada es de data más bien reciente. Podríamos decir que Sueños de la memoria de Teatro Ictus, estrenada en 2004, es un referente digno de mencionar que sostiene, a partir de la revisión de la trayectoria de la propia compañía, los estrechos vínculos entre la biografía personal, la creación artística y los hechos históricos. El año en que nací, estrenada en 2012, es probablemente un hito gravitante para la historia del teatro documental en nuestro país. Dirigida por Lola Arias - que en Argentina es una exponente reconocida de este género-, la obra instaló en escena a una serie de individuos (actores y no actores) para que compartieran su historia personal en relación al golpe militar y la posterior dictadura. Nicole Senerman, una de las actrices del montaje, que estuvo a cargo de la proyección de imágenes audiovisuales; ha desarrollado desde entonces varios talleres en torno al teatro documental, así como colaborado con la compañía La Laura Palmer - una de las exponentes más consistentes del teatro documental en el país-. Ella señala en una entrevista a Revista Hiedra que "En el fondo esas historias anónimas siempre están dentro de un contexto histórico ... Y eso es lo que hace que la historia oficial tenga efectivamente otros puntos de vista". Así, este cruce entre la experiencia privada y una lectura pública de los hechos, es la que permite incorporar nuevas visiones y lecturas conflictivas de la historia.

En la trayectoria de teatro KIMVN, este aspecto es gravitante, ya que su objeto de reflexión y representación es la comunidad mapuche y especialmente la visibilización de la violencia de la que son víctimas hasta hoy. Su directora descubrió hace algunos años su ascendencia mapuche y ha estado trabajando desde entonces en recuperar una historia construida a partir de testimonios. Es interesante que la dramaturgia de la obra, a cargo de David Arancibia Úrzua, fue luego intervenida por la directora para incorporar distintos testimonios articulados en la obra como una historia unitaria. Antes de referirme a los elementos específicos utilizados en Nuke, haré una breve mención al trabajo que la compañía realiza en una obra anterior, perteneciente a su trilogía documental. Me interesa cómo este montaje integra una relación cercana con la realidad histórica, encarnada en las presencias de los no-actores o actores naturales devenidos en documentos y la incorporación de la subjetividad como única encarnación posible de la experiencia. En el caso de Galvarino, quiero detenerme en la proyección audiovisual que se usa para presentar 
en la parte alta del escenario - a la manera que lo hacen a veces los subtítulos para obras en idioma extranjero- las cartas manuscritas (y que se van escribiendo como si asistiéramos a su representación "en vivo" en cada montaje) que la hermana de Galvarino, en la realidad Marisol Ancamil Mercado, envía a las autoridades para pedir que su hermano sea localizado. En este recurso se observa la convivencia entre el documento, la evidencia jurídica, el rastro histórico, y las ambigüedades de la carga subjetiva que habita en la prueba documental. François Jost y André Gaudrealt proponen en El relato cinematográfico que el límite que divide los géneros documental y de ficción en el cine no está dado tanto a priori como en la actitud del espectador. Estas obras combinan una actitud ficcionalizante y documentalizante, como estos autores las denominan, en el uso de los recursos audiovisuales, enriqueciendo la recepción de la obra en términos de desdibujar los límites entre la prueba fehaciente y la multiplicidad de la experiencia.

En el primer apartado hice referencia a la nomenclatura propuesta por Bazin para definir el espacio teatral y el fílmico como intenciones de mirada centrípeta y centrífuga, respectivamente. En un trabajo anterior dedicado a analizar el uso del recurso audiovisual en el teatro contemporáneo chileno, pude constatar que en esta oposición espacio centrífugo/espacio centrípeto, el aparato de proyección de imágenes solía estar más bien al servicio de una mirada dirigida y pormenorizada. En casi todos los casos estudiados, la idea de espacio centrífugo de Bazin se tensiona, en la medida que el aparato audiovisual no está ahí para abrir la escena hacia un "afuera", sino para mirar más detenidamente "dentro" de ella. Podemos decir que al analizar Galvarino desde la lógica baziniana, la proyección de las cartas manuscritas amplifica esa presencia hacia horizontes imposibles para la dimensión del escenario, deteniéndose en el detalle, en la mirada como zoom hacia ese objeto material; sin embargo, al mismo tiempo, abre el espacio de la escena hacia aquello que no está presente en ella. Creo que este último aspecto es central para entender la idea de documentalidad abordada por la compañía y por su directora.

Podemos decir, en primer lugar, que hay un elemento que persiste en toda su trayectoria y tiene que ver con la presencia de no-actores mapuche que encarnan personajes, a la vez que se encarnan a sí mismos como voz y presencia del discurso silenciado. Desde Ni Pu Tremen hasta Nuke, esta ha sido una decisión constante de la compañía. En ese sentido, la documentalidad aquí está encarnada doblemente en el documento y el testimonio: sus cuerpos como documento vivo y la elaboración de los testimonios encarnados en su rol escénico. En Ñuke, así como en obras anteriores, esta corporalidad no sólo surge como personaje que actúa y repite un texto, sino que se asienta también en la repetición de actividades cotidianas, que se 
realizan en el espacio teatral, y cuya temporalidad se respeta: pelar una gallina para luego cocerla, amasar churrascas y sopaipillas para luego cocinarlas.

Pero Ñuke da una paso más allá, y traspasa el territorio que separa a su público de la representación (ya mencionaré en qué sentido el diseño escenográfico es también una apuesta en ese sentido). Al final de la obra, la comida se comparte con el público, en una instancia de discusión que quiere promover el diálogo y la interacción entre quienes están en escena y quienes estuvieron antes, en silencio, observando. Otro elemento interesante es la inclusión de música en vivo, con intérpretes mapuche a cargo de la ejecución. Los músicos aparecen como un tercer espacio dentro de la escena, que no es del todo parte de la ficción ahí creada, pero la acompaña, tensionando el lugar de los actores, actrices y el del público.

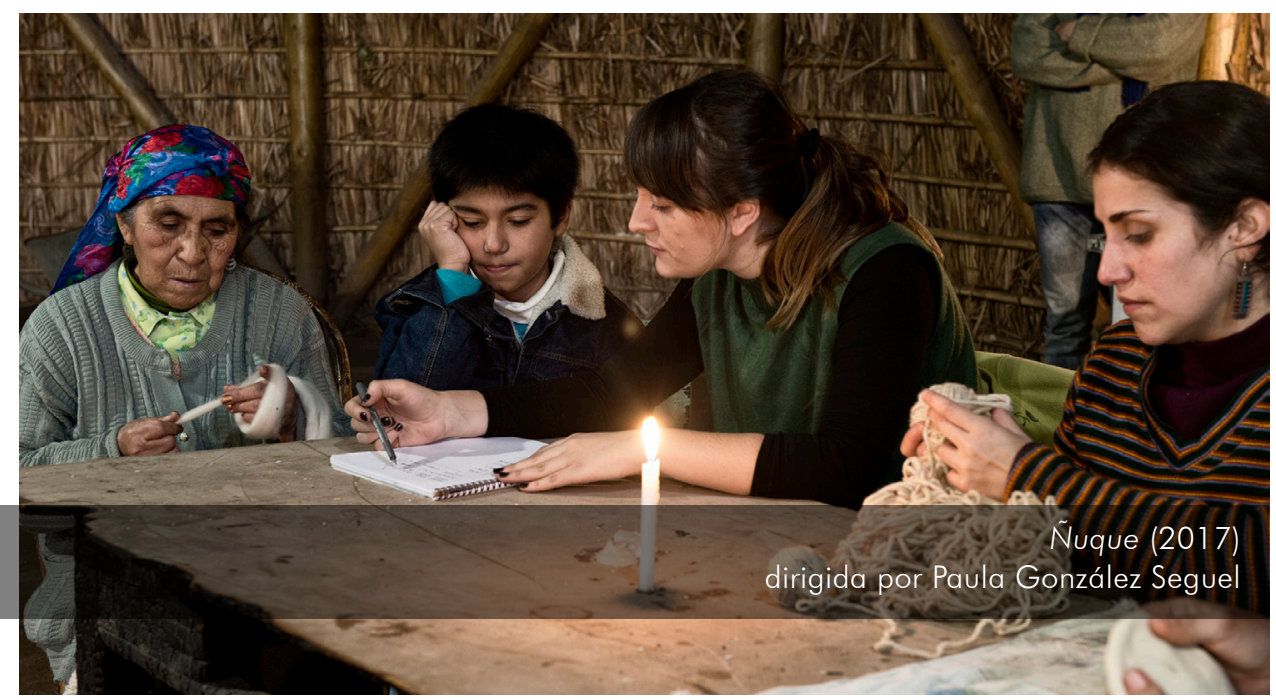

Probablemente el desplazamiento más radical en el trabajo documental de la compañía está dado en este último montaje, por la construcción de una ruka como lugar de la representación. No se trata de una escenografía que imita una ruka, sino una ruka con todas sus características que, al momento del estreno, se emplazó en la Plaza de la Cultura, ubicada a las afueras del Centro Cultural Estación Mapocho, y luego se instaló en el patio Central del Centro Cultural Gabriela Mistral (GAM), donde estuvo en temporada durante enero y parte de febrero de 2017. Los espectadores accedemos a un espacio que se constituye como zona íntima de una familia, su casa, a la vez que se exponen los aspectos comunes y colectivos de problemáticas que anidan en el ámbito político, cultural y social. Se crea esta casa para construir comunidad, ir hacia adentro (de una familia, de una serie de vivencias personales), 
para abrirse a lo social y desde allí debatir. Ñuke no utiliza ningún dispositivo de registro o proyección audiovisual, pero si intentáramos aplicar la aproximación que distingue una mirada centrípeta y una abierta más allá del espacio de representación, podríamos decir que el ejercicio en Nuke es cerrarse para construir un relato abierto. En este sentido, utilizar la nomenclatura de Bazin nos permite desplazar las reflexiones en torno a la imagen más allá del uso concreto de un dispositivo de proyección en escena, e instalar su propuesta más ligada a los modos de mirar, y las posiciones epistémicas asociadas a ellos, que la utilización de una tecnología en concreto.

Por último, la noción de documentalidad que se desarrolla aquí, dialoga muy fuertemente con su concepción contemporánea desde los estudios de cine, específicamente la noción de indeterminación ya descrita. Nuke propone una experiencia para el público asistente, desde la misma inmersión en la ruka, su piso de tierra, su particular luminosidad, donde lo que se representa en el centro del espacio no es lo único que está ocurriendo, sino también nuestra propia vivencia del lugar y de la conversación (y comunión a través de la comida) que se genera al final. Es también relevante que esa misma discusión y los testimonios que vemos encarnados en determinada dramaturgia, son también ellos parte del debate y de la realidad cultural de una comunidad invisibilizada. Me parece que, usando la nomenclatura de Jacques Rancière, no se trata ni del régimen mimético, ni del de la inmediatez ética, sino una apuesta política de representación estética, que modifica el mundo no porque su temática sea social, ni porque convoque a la participación pública, sino porque, desde sus propias prácticas discursivas, se entiende como parte de él.

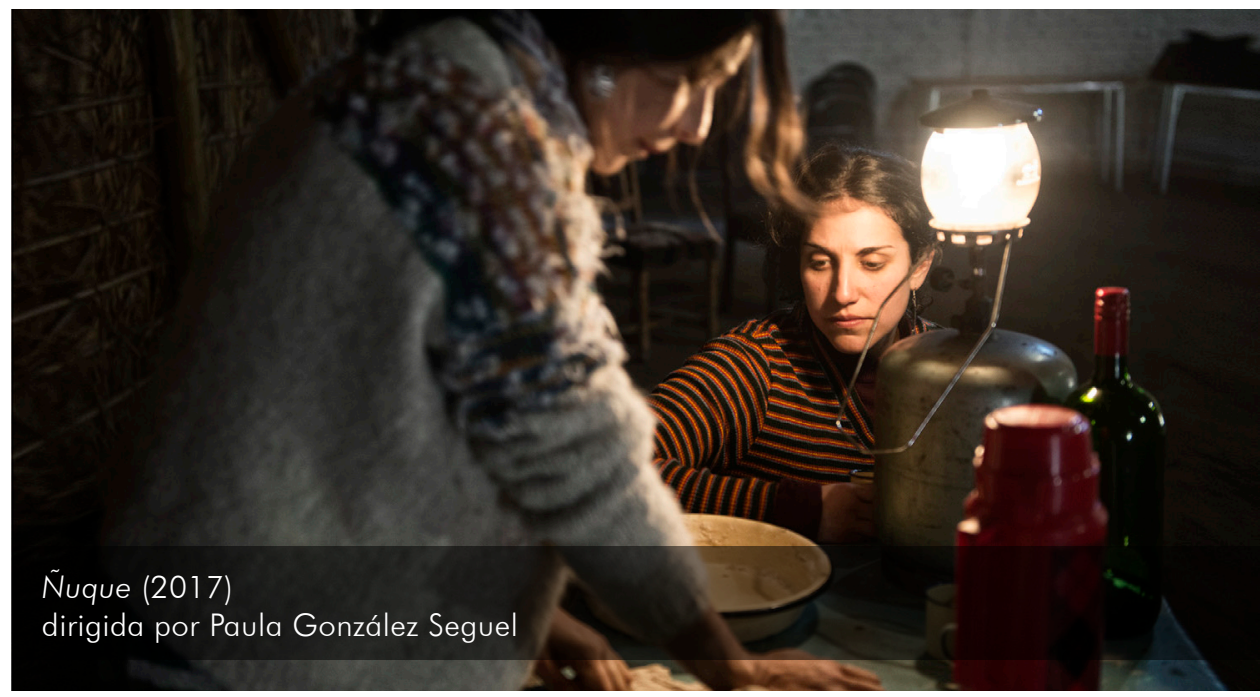




\section{Mateluna: el archivo descentrado}

En 2013, el dramaturgo y director teatral Guillermo Calderón estrenó Escuela, un montaje que se sumergió en las experiencias de individuos que habían pertenecido a guerrilla paramilitar en Chile durante la dictadura y su formación como tales en una suerte de sistema pedagógico de la resistencia. Con el estilo propio de Calderón, que ya había sido desplegado en su obra anterior Villa, caracterizada por una renuncia al juicio y la nostalgia; esta obra construyó relatos no convencionales y por lo mismo perturbadores, en torno al pasado político más reciente y su actualización en el presente. Uno de los colaboradores en la recopilación de información fue Jorge Mateluna, ex militante del Frente Patriótico Manuel Rodríguez (FPMR), que compartió con el director y su compañía detalles de su biografía que estaban vinculados a su formación como frentista. Mateluna, la obra de Calderón estrenada en 2016, gira en torno a la situación real de este individuo, quien había sido acusado de participar en el asalto a un banco en 2013, y que al momento del estreno -y hasta la actualidad-cumplía su condena en una cárcel de alta seguridad en Santiago de Chile.

La puesta en escena de Escuela está sobre todo estructurada a partir de la recreación de las situaciones de adiestramiento y preparación relatadas por quienes las vivieron de primera fuente. No hay en ella ningún elemento que pudiéramos considerar propiamente documental ni tampoco se utiliza en el escenario ningún tipo de dispositivo audiovisual. La excepción a esta descripción surge en lo que podríamos denominar el epílogo de la obra, cuando una fotografía es proyectada sobre el fondo del escenario y los actores y actrices la contemplan dando la espalda al público. Esa imagen, que muestra a un grupo de adolescentes mientras hacen un rallado contrario a la dictadura de Pinochet, es una fotografía donde aparece el propio Calderón con sus compañeros de época. Si no se conoce la procedencia del material no es posible concluir que se trata de él ni por lo tanto señalar este material como archivo documental. No hay señales de reconocimiento ni ningún elemento de la diégesis de la obra en ese sentido. En una gira que realizaban en la ciudad de Nueva York, personas cercanas al director que tuvieron acceso a esta información la señalaron como relevante y llevaron a que la compañía tomara la decisión de hacer explícita su cualidad de archivo y la relación biográfica con el autor y director de la obra. De hecho, se incluyeron también una serie de textos que individualizaban a los demás sujetos retratados, especificando su nombre y algunos hechos que describieran su situación actual. Para Calderón, el último en ser identificado, se exponía el escueto: "Y este es el dramaturgo de la obra". Hacer evidente esta relación otorgó una cualidad distinta a las funciones en las que se incluyó, poniendo énfasis en la relación biográfica, afectiva y de compromiso 
político que estaba presente en la obra desde las motivaciones del mismo autor. Pero no sólo en el sentido de pensar este montaje inscrito en la historia personal de Guillermo Calderón, sino más bien interrogando la escena con la presencia mediada de un cuerpo (cargado de historicidad) que tensiona el espacio compartido con sus compañeros y compañeras. En ninguna de las temporadas montadas en Chile se manifestó esta vinculación de manera explícita. Sin embargo, para el trabajo actoral de los demás miembros de la compañía, esa presencia es un elemento relevante en la definición del marco de la escena y la relación entre quienes se sitúan en ella. En ese momento Calderón está ahí también, señalado por una imagen del pasado que dialoga con la historia de los protagonistas no presentes. En esta conjunción el documento adquiere su carácter de prueba o evidencia de unos hechos, pero sólo al servicio de poner esos hechos en juego en un cruce de biografías y subjetividades. Mónica Bernabé, en una reflexión en torno a lo que llama "narrativas del presente", a partir de un breve escrito de Sergio Chejfec sobre lo que él identifica como "relatos de la documentalidad" - para dar cuenta de una tendencia a incorporar en la narrativa contemporánea elementos de carácter documental-, destaca justamente esta naturaleza paradójica del fenómeno, en que el material que tradicionalmente se considera portador de una carga objetiva, en una relación distanciada y fidedigna con los hechos, es aquella que ingresa al texto para dar señales de la potencia afectiva de su relación con una biografía. En su aproximación, es el mismo extrañamiento provocado por los mecanismos de reproducción audiovisual el que reclama un regreso al cuerpo biográfico en el que ese instante se enmarca:

La distancia que separa cuerpo e imagen, voz y escritura, instaura una zona indeterminada, una especie de heterotopía cyber, que pone en relación diferentes dispositivos narrativos para señalar los dilemas del reconocimiento de sí mismo y de los otros. Las narrativas del presente asumen un rasgo fuertemente autobiográfico en el intento de recuperar algo de la perturbación provocada por la experiencia estética en medio del paisaje en que se desarrolla la cosificación de las relaciones humanas $(\mathrm{s} / \mathrm{n})$.

Así, la fotografía de Calderón proyectada sobre el espacio escénico es mucho menos una prueba de veracidad que una alusión a la textura subjetiva de cualquier hecho.

De todas formas, cualquier archivo, incluso aquél que desafía sus propias funciones, se articula desde al menos dos nociones: un origen y una norma que lo autoriza. O como puede describirlo Jacques Derridá en Mal de archivo: como principio y mandato. El archivo funciona temporalmente porque siempre alude a ese 
tiempo en el que su calidad de tal aún no podía ser activada: el futuro para el que es resguardado, y el presente en el que ese sentido se actualiza. Pero para que esa operación cruzada por la temporalidad efectivamente se sancione, se debe autorizar una interpretación que justifique su presencia como tal en una ordenación dada. El arconte correspondiente a todo archivo, permite que sea leído de tal o cual manera, reduciendo los modos posibles de vincularse con él. Teniendo esto en cuenta es que podemos ahora entrar al análisis de Mateluna y su inscripción documental desde la utilización de materiales de archivo y de la proyección de imágenes en movimiento como parte de la puesta en escena.

En la obra hay distintos modos de utilizar la proyección de imágenes visuales y audiovisuales en escena, así como usos problemáticos de ese material si queremos definirlo como archivo. Para intentar una categorización organizaremos estos usos en cuatro modelos cuya ordenación no obedecen a su orden de aparición en la obra ni a su importancia, sino a la disposición de estos en el consiguiente análisis: 1) la imagen fija como resignificación de una presencia; 2) los "registros" de obras en proceso como marcas de verosimilitud; 3) la evidencia probatoria y su deconstrucción; 4) la reconstrucción de escena. Me referiré sólo a los tres primeros.

Voy a comenzar por el primer modelo identificado, para ponerlo en diálogo con la descripción anterior de la imagen proyectada al final de Escuela. Mateluna finaliza también con una foto fija expuesta en el escenario. Se trata de una fotografía de Jorge Mateluna, en que aparece frontal y sonriente frente a la cámara. Podemos reconsiderar la relación que esta presencia mediada tiene con la diégesis en comparación con el caso anterior. En esta obra podríamos decir que también el sujeto representado entra a escena por medio de su imagen proyectada, pero esta vez está plenamente identificado como el protagonista -como actante, no como personajede la obra. Hemos asistido ya a la revelación de su inocencia y hemos compartido con el elenco el proceso de desarrollo de la propia obra. En este caso la presencia en escena es una apertura hacia el real histórico con el que ese cuerpo mediado se vincula: el fracaso de un sistema de justicia corrupto y los esfuerzos por devolver a Jorge Mateluna su libertad. En gran parte de las funciones un grupo de activistas que lidera las gestiones para reabrir el juicio y poder probar la inocencia de Mateluna se reúne a la salida de la función donde despliega sus pancartas buscando crear conciencia frente al caso y sumar adherentes. De algún modo estas pancartas, sin requerir de un parecido en términos icónicos con su referente, funcionan también como el recordatorio tangible de la materialidad de ese cuerpo y la experiencia asociada a este, excluidos de nuestra vista a causa de una prisión injusta. Calderón ha señalado en una entrevista que esta obra abrió para su trabajo un nuevo camino que hasta ahora no había explorado, el de la incidencia directa en el universo para- 
textual de la obra. En ese sentido podemos decir que se trata de uno de los grados de documentalidad en que el montaje opera como artefacto de incidencia en lo real, no sólo como representación. De algún modo, la fotografía como archivo, señal de la presencia de Mateluna, puesta en diálogo con las manifestaciones cargadas de performatividad que se desarrollan en el espacio contiguo al edificio teatral, es un lugar de tránsito entre el territorio del texto escénico y lo que lo circunda.

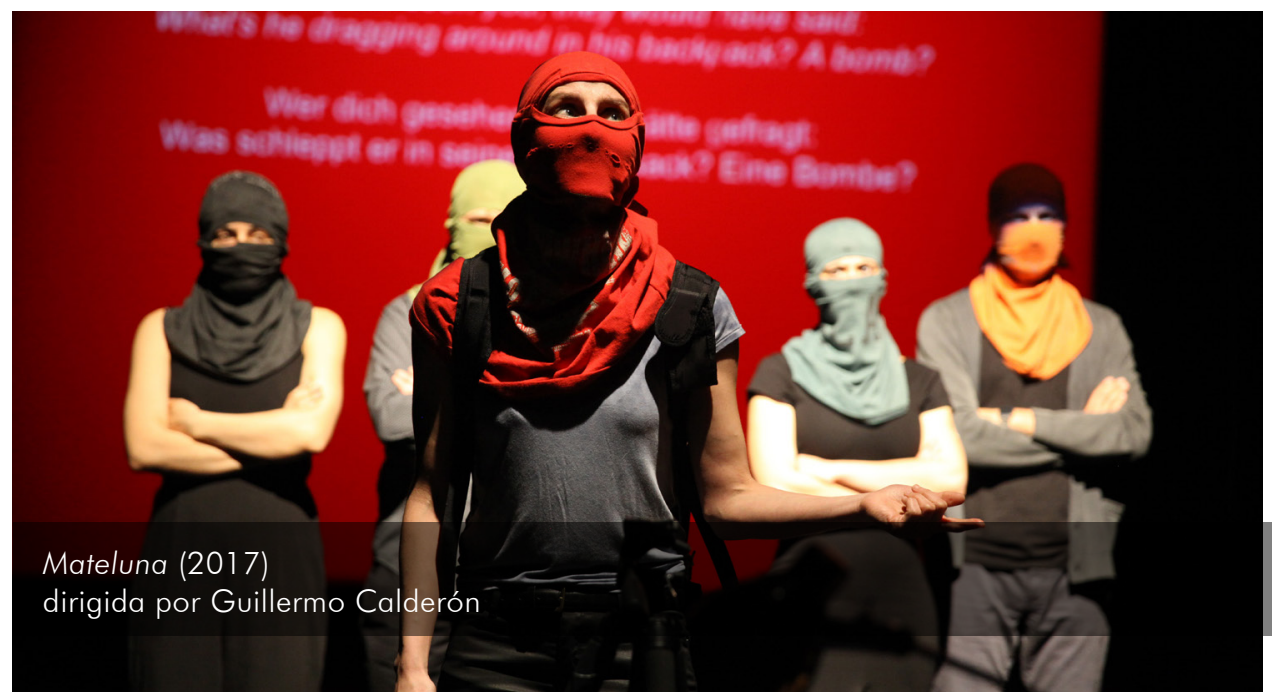

Por otro lado, como parte del segundo modelo, hay dos videos que se exhiben durante las funciones y forman parte de uno de los recursos principales del relato escenificado. Se trata de inserciones en las que se hace referencia a pruebas de ensayo y error, y muestran la evolución del proceso creativo, a través de otros intentos por llevar a escena la historia del protagonista ausente. No en todas ellas se utiliza el dispositivo tecnológico. Las dos ocasiones en que se lo hace corresponden, una, al registro efectivo de una función de Escuela donde se muestra a los actores y actrices encapuchados, sentados en ronda, mientras uno de ellos representa al personaje que les enseña cómo hacer una bomba. La obra anterior se presenta como antecedente de la actual y el registro audiovisual como prueba y reactualización de su contenido. En esta escena se utiliza una estrategia que se repite en el segundo ejemplo, y es la de replicar en el escenario lo que se presenta en el video. Este modo de enfrentar el archivo lo sitúa remedando su cualidad ficcional, en una dialéctica que por un lado reafirma su carácter de legitimidad y por otra lo subvierte al reforzar su inscripción en el espacio de la representación. La modalidad que adquiere este recurso es el de sobreimprimirse en la imagen de fondo, pero también en ocasiones adelantarse a ella, como si la acción en presente (pero replicada y 
por tanto siempre ficcional) pudiera predecir o provocar la emergencia del registro probatorio. Esta estrategia de representación está muy en concordancia con una apuesta estética autorreflexiva y que caracteriza en gran medida a este montaje. Mateluna, nos muestra su propia realización, y en este sentido, se emparenta con el documental performático catalogado por Nicholls y la performatividad de todo documental señalada por Brussi.

Las obras aludidas no son sólo una manera de poner en escena el proceso creativo (aunque en un caso se trate de un ejemplo ficcionado), pero su confrontación con la réplica diferida en escena pone en situación el espacio representado como uno en construcción. Aquí me gustaría recoger lo que plantea Yamila Volnovich acerca de lo que denomina "la función documental", que en el texto del mismo nombre utiliza para definir una propiedad de este género cinematográfico:

En este contexto, más que atreverme a definiciones ontológicas o abismarme en delicadas taxonomías, he preferido aquí ensayar un aproximación operativa y afirmativa, focalizando las estrategias textuales que inscriben la materialidad del cuerpo de la obra, en su propio proceso constructivo, una posición reflexiva sobre el dispositivo técnico de producción de imágenes. . . La función documental, entendida como fuerza performativa, debe problematizar estas condiciones de producción. En términos semióticos, hace de la función pragmática del texto su marca semántica (332).

En este planteamiento, Volovich reconoce la necesidad del discurso documental de pensarse a sí mismo como un acto de mirada que ubica siempre la estética como un aspecto inseparable de la política. En una reflexión similar, Anna María Guasch intenta una caracterización de lo documental en los siguientes términos: "Lo documental es una manera de enmarcar la realidad o, en otras palabras, el lugar en el que la función referencial de la imagen y el sonido filmográfico reflexionan sobre sus principios operativos y se cuestiona su identificación con el mundo empírico y fenomenológico" (352). En el caso de Mateluna esta relación es evidente, y las dos categorías anteriores nos ayudan a entender la estrecha relación entre la obra teatral y su diálogo con un espacio extradiegético pero en un sentido de intercambio recíproco. No se trata de una noción cándida de la obra como reflejo del mundo ni tampoco de efecto concreto sobre una realidad dada; sino de entender ambos espacios como lugares en construcción que se nutren mutuamente. La obra habla también de sí misma y en ese gesto invoca, a la vez, una preocupación por sus márgenes en colaboración con el real histórico al que alude.

Sobre el último modelo de uso del archivo identificado anteriormente y en vínculo con el dispositivo tecnológico, podríamos decir que se trata de un documento 
matriz que se utiliza de modo paradójico y sostiene lo que podríamos denominar la premisa ética de la obra. Muy al inicio se proyecta el video de reconocimiento de uno de los sospechosos del asalto. Este registro pertenece a carabineros y en ese sentido su resguardo y proceso de conservación tiene como finalidad el sostener un discurso de veracidad que fundamente decisiones y procesos llevados a cabo por la institución. Es decir, se trata de un archivo que quiere cumplir, de modo convencional y unívoco, la tarea de activar en el presente un cierto sentido ya sancionado de la historia. Así es como el elenco lo presenta y nos predispone a leerlo sin suspicacias, mostrándonos el momento en que Jorge Mateluna es aparentemente individualizado. Este video es una marca que en el proceso judicial grafica la prueba de reconocimiento. Es decir, la evidencia es la identificación, y el video su manera de permanecer y validarse.

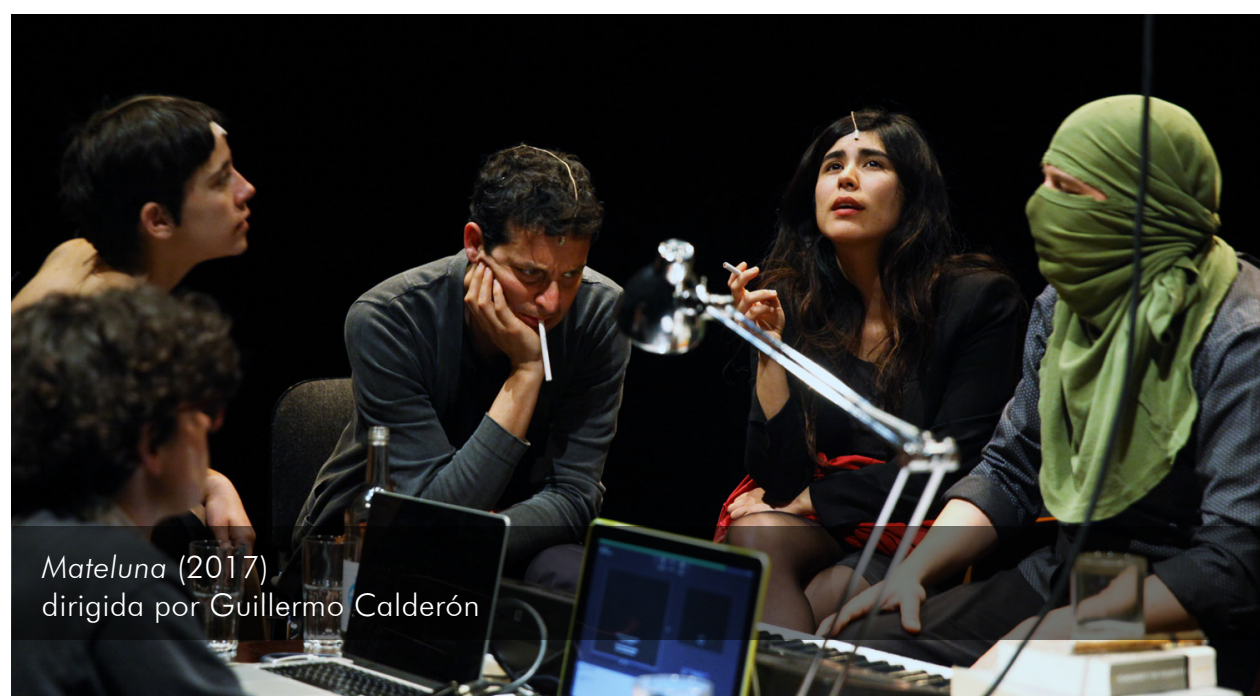

Sin embargo, el giro radical que toma el relato de los hechos está sostenido por una nueva lectura del mismo material. Hacia la mitad de la obra se revela que en una visita a Jorge Mateluna en la cárcel, este les asegura no haber estado involucrado en el asalto. La compañía, que hasta entonces se había dedicado a comprender y justificar mediante diversas puestas en escena (reales e imaginarias) se dedica ahora a investigar más profundamente los detalles del juicio y la condena. Como parte de este ejercicio es que vuelven a exhibir frente a los espectadores el video antes utilizado para demostrar la participación de Mateluna en el acto delictual, pero ahora se nos presenta desnudando la primera mentira y develando que el auténtico Jorge Mateluna no es aquél que el testigo identifica. Ya en un nivel muy primario, 
este gesto expone una gran declaración respecto de la fragilidad del archivo y la ambigüedad de las imágenes. No son pocas las aproximaciones provenientes del campo de los estudios visuales que enfatizan la relevancia del vínculo entre imagen y palabra. En cuanto a la concepción de una imagen de archivo, recurro a la idea de una de carácter nómade descrita por Mariela Cantú, cuando hace referencia al diálogo entre imágenes que se produce en el cine de archivo o found footage. No podría en este caso hacerse un paralelo con la obra de Calderón en el sentido de un teatro "de archivo", pero sí podemos extrapolar la posición de Cantú para reconocer en el nomadismo del registro utilizado, la posibilidad de inscribirse en discursos no sólo diversos sino que contradictorios. En el planteamiento de Cantú, estas imágenes sin sentido ni origen determinado, pueden recuperar algo de ese sentido inasible a partir del trabajo que este sistema de relaciones promueve. Me atrevo a decir que las operaciones desarrolladas por Calderón y su equipo reestablecen una significación justamente en el gesto de deconstruir su potencial de veracidad. La estrategia de no presentar inicialmente el archivo como prueba del engaño, sino por el contrario, engañarnos con él, establece una relación compleja con el material. Ya no es verdadero ni falso, en un sentido absoluto, es un elemento que puede constituirse como discurso incluso con intenciones opuestas. De algún modo recorremos el mismo camino que los miembros de la compañía al buscar una justificación a los actos de Jorge Mateluna y luego descubrir la trampa. Así, el archivo es extirpado de su domiciliación establecida para, en una primera instancia refrendar esa validación, pero luego desmontarla. Este archivo audiovisual nómade encuentra su contraparte en un archivo sonoro que lo sobreviene en el tiempo de la representación, y que muestra el propio develamiento, dentro de la institución, de la anomalía del video como evidencia. Es interesante que la decisión de puesta en escena es la de exponer esos sonidos como imágenes, pero no traduciéndolas a representaciones icónicas, sino que reforzando el carácter convencional de esos signos, al insistir, como si se tratara de alguien que toma nota de aquello que se dice, en repetir lo que el audio atestigua. Las palabras presentadas aquí como figuras y como voces, parecen repetir el diálogo entre los videos antes descritos, en que los montajes anteriores (real y ficticios) se encuentran en escena con su propia representación. 
En resumen, me parece que la utilización del archivo en Mateluna, puede muy bien describirse a partir de la siguiente cita de Hito Steyerl:

Por un lado, la articulación, la producción y la recepción de un documento está profundamente marcada por las relaciones de poder y está basada en convenciones sociales. Por otra parte, aunque, el poder de un documento descansa en el hecho de que está previsto que pruebe lo impredecible dentro de estas relaciones de poder - debe ser capaz de expresar lo que es inimaginable, inefable, desconocido o incluso monstruoso- y por tanto crear la posibilidad de cambio. (en línea)

En todos los usos del archivo analizados, hay un movimiento que expone las relaciones de ese archivo y el poder, a la vez que al develar su naturaleza política, hace aparecer un modo de documentalidad que renueva el sentido del archivo original.

\section{Dentro y fuera de la escena}

Mi propósito inicial era presentar, en estos dos casos representativos, una tendencia en el teatro chileno reciente por incorporar estrategias documentales en su puesta en escena, los modos particulares en que se hacían cargo de una idea de documentalidad. En el caso de $\tilde{N} u k e$, a través de la presencia de no-actores de origen mapuche -estrategia menos relevante en este último montaje que en obras anteriores de la compañía- pero sobre todo en la creación de un espacio que se habita de manera documental y que instala "la realidad", no fuera del espacio escénico sino integrada a sus propios códigos, sin intentar influir en ella desde la diferencia sino porque el discurso estético es también un hecho de esa realidad. En el caso de Mateluna, el uso del archivo de modo reiterado está al servicio del desenmascaramiento de su modo de operar. El archivo como un objeto que tiene lugar autorizado por un poder que lo legitima, pero que la obra deconstruye en escena, creando así un territorio de disidencia que se impregna de los hechos a los que alude en su inscripción extradiegética.

En una entrevista realizada por Carmen Guarini a Jean-Louis Comolli, el teórico y realizador francés expone lo que considera las distancias entre lo real y la realidad como consideraciones útiles al pensar su posible representación en imágenes:

Lo real es lo que el cine no puede alcanzar sino de manera azarosa, ocasional, por efracción. Porque en el cine, y esto incluye al documental, todo se mantiene a distancia, lo real es lo accidental, el azar. Es lo que viene a perturbar el gesto cinematográfico. Mientras que la realidad es otra cosa, es el conjunto 
de sistemas de reproducción social de convenciones sociales donde el mundo tiene ya un rol y es con eso que uno trabaja. Y si uno trabaja con eso, reconoce que es esa realidad la que pone en escena en gran parte del film. Nosotros volvemos a poner en escena (158).

Ambos trabajos, haciendo uso de estrategias distintas de documentalidad, despliegan este develamiento de la realidad, para hacerse cargo de cuestiones políticas urgentes, a través de un discurso estético que se escenifica como un real del que también forma parte. 


\section{Obras citadas}

Barría, Mauricio. "Emergencias documentales. Retorno de la historicidad y de un nuevo teatro político". LASA Cono Sur, Santiago de Chile. 05 ago. 2015. Ponencia.

Bernabé, Mónica. "Las viejas narrativas del presente”. Revista Anfibia. Revisado el 12 de agosto de 2017. http://www.revistaanfibia.com/ensayo/las-viejasnarrativas-del-presente/

Bazin, André. “Teatro y cine”. ¿Qué es el cine? Madrid: Rialp, 2004.

Bernini, Emilio. "La indeterminación”. Jorge La Ferla y Sofía Reynal (comps.) Territorios audiovisuales. Buenos Aires: Libraria (2012): 295-310.

Bravo Rozas, Cristina. "El nuevo teatro documento en Argentina, Uruguay y Chile: la reapropiación de la memoria". Acotaciones n 37 (2016): 117-142.

Bruzzi, Stella. New Documentary: A Critical Introduction. London: Routledge, 2000.

Derridá, Jacques. Mal de archivo. Madrid: Editorial Trotta, 1997.

Gallardo, Ítalo y Nicole Senerman. “¿Teatro documental, teatro biodramático?”. Revista Hiedra. (2015). Revisado 04 de junio de 2017. http://revistahiedra.cl/ entrevistas/teatro-documental-teatro-biodramatico/

Graudreault, André y François Jost. El relato cinemtográfico. Ciencia y narratología. Barcelona: Paidós, 1990.

Guarini, Carmen. "Cuerpo filmante, cuerpo filmado. Entrevista a Jean-Louis Comolli”. Antropología visual de la ausencia. Buenos Aires: Sans Soleil (2017).

Guasch, Anna María. "El giro documental". El arte en la era de lo global. 1989-2015. Madrid: Alianza. 2016: 349-389.

Lehman, Hans-Thies. Teatro posdramático. Murcia: CENDEAC, 2013.

Orellana, Constanza; Constanza Silva y Fabiola Vilches. "Lo biográfico, lo testimonial y lo documental como instrumentos para la puesta en escena". Tesis Universidad de Valparaíso, 2017.

Rancière, Jacques. "Las paradojas del arte político". El espectador emancipado. Buenos Aires: Manantial. 2010: 53-84.

Sontag, Susan. "Film and Theatre". Tulane Drama Review, 11.1, (1966): 24-37. 
TEATRO RECIENTE EN CHILE Y ARGENTINA: DOCUMENTO, VIOLENCIA Y POLÍTICA

Steyerl, Hito. "Política de la verdad". blogs\&docs. Traducción de Elena Oroz. Junio 2009. Revisado 10 de septiembre de 2017. http://www.blogsandocs.

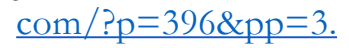

Volnovich, Yamila. "Actos de ver. La función documental”. Territorios audiovisuales. Comps. Jorge La Ferla y Sofía Reynal. Buenos Aires: Libraria. 2012: 326-339. 